p-ISSN: 1412-1697; e-ISSN: 2477-3816

http://jurnal.radenfatah.ac.id/index.php/intizar

\title{
Penggunaan Model Pembelajaran Berbasis Aktif Learning Tipe STAD untuk Meningkatkan Hasil Belajar Peserta Didik pada Mata Pelajaran Aqidah Akhlak
}

\section{Dedi Wahyudi}

Institut Agama Islam Negeri Metro Lampung, Indonesia

Email: podoluhur91@gmail.com

\section{Mahmudatun Hasanah}

Institut Agama Islam Negeri Metro Lampung, Indonesia

Email: mahmudatunhasanah17@gmail.com

\begin{abstract}
Abstrak
Akhlak di kehidupan sangatlah perlu sehingga memberikan kontribusi positif kepada setiap manusia, dalam penelitian ini peneliti mengemukakan bahwa seorang yang berakhlak baik akan memberikan keindahan untuk dirinya dan orang lain yang berada di sekitarnya, perlu kita ketahui terdapat akhlak terpuji dan akhlak tercela, yang harus ditanamkan yaitu akhlak yang terpuji untuk memancarkan cahaya yang terang dalam kehidupan, dalam tulisan ini penulis mengamati apakah model pembelajaran Stad ini dapat meningkatkan hasil belajar siswa pada mata pelajaran aqidah akhlak, di mana di sini akhlaklah yang diutamakan. penulis menerangkan bagaimana seorang guru seharusnya mengajar, mengajar itu bukan hanya mentransfer materi namun memupukannya dengan keterampilan-keterampilan dan hal-hal yang baru, sebagian besar seorang guru yang mengajar di sekolah khususnya mata pelajaran Aqidah Akhlak yang memberikan materi peserta didik diperintah menulis dan mendengarkan ceramah guru, yang menimbulkan peserta didik bosan dan jenuh untuk mengikuti proses belajar mengajarnya, sehingga dalam pemahaman materi kurang, dan mengakibatkan peserta didik hasil belajarnya rendah. maka penulis di sini mencoba menerapkan model pembelajaran berbasis Aktif Learning Tipe Stad untuk membantu siswa dalam meningkatkan hasil belajar, metode penelitian yang digunakan di sini adalah studi pustaka di sini penulis memberikan pengajaran dengan model pembelajaran Tipe Stad tersebut dengan tujuan untuk meningkatkan hasil belajar siswa, serta memupuk keterampilan-keterampilan dan memberikan siswa faham akan materi yang diberikan. penulis menggunakan studi pustaka dalam membuktikan keberhasilan atau tidaknya model pembelajaran ini, dengan menelusuri ke perpustakaan dan mencari data dari penelitianpenelitian terdahulu yang ada dalam buku-buku yang dibaca, penelitian ini harapannya untuk membuktikan bahwa dengan model pembelajaran Stad ini murid menjadi giat dan cepat menangkap materi dari pendidik dan hasil belajar peserta didik dapat memuaskan hati
\end{abstract}

Intizar, Volume 23, Nomor 2, 2017 
Dedi Wahyudi \& Mahmudatun Hasanah

Penggunaan Model Pembelajaran Berbasis Aktif Learning Tipe STAD untuk Meningkatkan Hasil Belajar Peserta Didik pada Mata Pelajaran Aqidah Akhlak

pendidik yang melihat siswa yang ditransfer ilmu oleh dirinya dapat berhasil mendapat nilai bagus.

Kata Kunci: Model Pembelajaran STAD, Hasil Belajar, Aqidah Akhlak

Tantangan dan perkembangan pendidikan di Indonesia pada masa yang akan datang semakin besar dan kompleks. Hal ini membuat setiap guru pada jenjang sekolah dasar sampai sekolah menengah atas harus lebih menyiapkan diri dalam menyumbangkan ilmu pengetahuan yang mereka miliki, oleh Karena itu seorang guru harus lebih siap dan tanggap dalam mengembangkan kreativitas untuk membuat seluruh muridnya mendapatkan bekal yang cukup untuk menghadapi tantangan-tantangan dimasa yang akan datang (Arifin, 2012, hal. 38). Dalam hal ini tentunya harus diimbangi dengan kualitas guru yang memadai sehingga tidak terjadi kesenjangan, dikarenakan pada saat ini pendidik banyak yang hanya menggugurkan kewajibannya untuk mengajar. Namun, jarang memberikan appersepsi ataupun melakukan hal-hal yang bisa membuat peserta didik nya maju, terampil, dan berinovasi.

Pendidikan menciptakan inovasi-inovasi baru yang akan membuat perubahan di kehidupan saat ini dengan pembekalan aqidah akhlak yang baik, serta dibarengi dengan ilmu pengetahuan dan teknologi yang akan menjawab tantangan dimasa yang akan datang. Sekolah yang menjadi salah satu bagian terpenting dalam mengembangkan karakter, sikap, kepribadian peserta didik. Peserta didik dapat mengembangkan segala keterampilannya dengan sebaik mungkin, dan diberikan apa yang dibutuhkan dalam hal ilmu pengetahuan agama maupun yang umum.

Aqidah akhlak adalah mata pelajaran wajib yang ada di sekolah dan memiliki pengaruh yang sangat baik untuk lebih didalami. Aqidah akhlak ini merupakan mata pelajaran yang membahas tentang Aqidah Islam, Akhlak, Rukun Iman, Rukun Islam, Adab Bergaul, Kisah-Kisah Asbabul Kahfi dan sebagainya. Namun, dalam proses penyampaian materi, kekurangan yang timbul terdapat pada pemakaian model pembelajaran sebagian besar dilakukan dengan model pembelajaran yang berpatokan pada gurunya yang aktif. Murid hanya mendengar, mencatat, menghafal dan akhirnya jenuh dengan apa yang diperintah guru. Guru itu bukan hanya menyampaikan materi setelah itu usai dalam tanggung jawabnya. Namun, guru harus juga memahami tentang karakter, keterampilan, dan kecerdasan anak (Wahyudi \& Alafiah, Studi Penerapan Strategi Pembelajaran Berbasis Multiple Intelligences dalam Mata Pelajaran Pendidikan Agama Islam, 2016).

Intizar, Volume 23, Nomor 2, 2017 
Akhlak merupakan wujud dari dalam diri seseorang yang merupakan hasil didikan dari kedua orang tua, guru, dan masyarakat di sekeliling kita, yang dikenalkan diarahkan dan di didik sejak kita masih kecil, agar kita berakhlak mulia, pembentukan akhlak harus dilakukan dengan sungguh-sungguh dan terus menerus baik dari keluarga maupun melalui lembaga pendidikan melalui bimbingan akhlak yang baik maka akan mengantarkan seseorang bertingkah laku mulia. Jadi, pembentukan akhlak ini sangat penting dilakukan sejak dini (Nilyati, 2015).

Kehidupan yang berjalan pada saat ini membutuhkan manusia yang ikhlas, berlaku jujur, dan disiplin sehingga Negara ini menjadi Negara yang damai dan tentram. Oleh karena itu program utama yang harus kita perjuangkan dalam pendidikan adalah menumbuhkan dan membina akhlak peserta didik dengan sungguh-sungguh sehingga dapat menjadi generasi-generasi yang akan memimpin Negara dengan baik dan benar (Mahdi, 2016). Akhlak meliputi seluruh aspek yang ada pada diri manusia, baik secara horizontal, terlebih vertical. Akhlak adalah perbuatan itu sendriri dan perbuatan selalu melahirkan akibat yang baik dan buruk (Irwandra, 2014).

Pembelajaran pada dasarnya merupakan jalinan komunikasi yang harmonis antara peserta didik dengan lingkungannya sehingga terjadi perubahan tingkah laku yang semakin hari semakin menuju kearah yang lebih baik (Wahyudi \& Azizah, 2016). Untuk mewujudkan semua itu di dalam proses pembelajaran maka harus efektif, menarik, mudah dipahami, membuat aktif peserta didik dan tidak membosankan, maka diperlukan suatu model pembelajaran yang mendukung dan mengikuti perkembangan zaman yang cepat berkembang dan maju, di dalam setiap masing-masing sekolah kita ketahui bahwa perbedaan dalam penyampaian guru dalam mengajar pasti banyak sekali, ada guru yang hanya melakukan pembelajaran dengan metode ceramah, dan lain sebagainya, dengan adanya perbedaan tersebut itu akan mempengaruhi peserta didiknya dalam menangkap pelajaran, serta memahami dari apa yang disampaikan oleh pendidik tersebut. Dalam pembelajaran aqidah akhlak ini peserta didik diharapkan tidak hanya membaca, menghafal, memahami isi dari pelajaran tersebut. Tetapi, memperoleh kecakapan dan keterampilan tersendiri bagi siswa.

Perubahan yang dapat dilakukan secara nyata adalah perubahan dalam proses pembelajaran yang dilakukan guru di dalam kelas, hal ini didukung oleh pernyataan degeng "bahwa proses pembelajaran merupakan pengaitan pengetahuan baru pada struktur kognitif yang sudah dimiliki siswa" bahwa dalam kegiatan belajar di sini siswa menghubungkan pengetahuan baru, dengan arti lain bahwa 
belajar dapat menjadi pengalaman keterampilan dan kemampuan berfikir. Di sini penulis mendapatkan suatu model baru yaitu model pembelajaran yang menurut pandangan penulis cocok dengan peserta didik masa kini, di sini model pembelajaran yang ingin penulis gunakan adalah berbasis aktif learning tipe STAD. Memang terdengar sedikit asing di telinga, namun pembelajaran model ini dapat mencipatakan proses belajar dengan Aktif.

Model pembelajaran Aktif Learning tipe STAD ini dikembangkan oleh Robert Slavin dan kawan-kawan dari universitas John Hopkins. Metode ini digunakan para guru untuk mengajarkan informasi akademik baru kepada siswa setiap minggu, baik melalui penilaian verbal maupun tertulis. Model ini memiliki langkah-langkah antara lain: Membentuk kelompok yang anggotanya 4 orang secara heterogen (campuran menurut prestasi, jenis kelamin, suku, dll) setelah itu guru menyajikan pelajaran dan guru memberi tugas kepada kelompok untuk dikerjakan oleh anggota-anggota kelompok, sesudah itu setiap Anggotanya yang sudah mengerti dapat menjelaskan pada anggota lainnya sampai semua anggota dalam kelompok itu mengerti. Setelah selesai guru memberi kuis/pertanyaan kepada seluruh siswa. Pada saat menjawab kuis tidak boleh saling membantu dan terakhir guru memberi evaluasi dan kesimpulan (Majid, 2013, hal. 156).

Terkait dengan hasil belajar, di sini dijelaskan dahulu arti dari belajar itu sendiri, menurut oemar hamalik belajar merupakan suatu proses perubahan tingkah laku individu melalui interaksi dengan lingkungannya (Arsiyati, 2012). Jadi belajar aktif adalah suatu sistem belajar mengajar yang menekankan keaktifan siswa secara fisik, mental intelektual dan emosional guna memperoleh hasil belajar yang berupa perpaduan aspek kognitif, afektif, dan psikomotorik (Nurwati, 2010).

Djamarah menyatakan hasil belajar adalah prestasi dari suatu kegiatan yang telah dikerjakan, diciptakan baik secara individu maupun tim. Menurut bloom dan ditulis kembali oleh sudjana secara garis besar membagi hasil belajar menjadi tiga ranah yaitu: ranah kognitif, ranah afektif dan ranah psikomotorik berkaitan dengan hasil belajar berupa keterampilan dan kemampuan bertindak (Maisaroh \& Rostrieningsih, 2010).

Agus Suprijono mengatakan hasil belajar adalah pola-pola perbuatan, nilainilai, pengertian-pengertian, sikap-sikap, apresiasi dan keterampilan. Dengan adanya proses belajar diharapkan perubahan perilaku tersebut menuju kearah yang baik. Semua itu guru yang menjadi sumber kuncinya selain menyampaikan materi guru juga dituntut untuk mereformasi pendidikan dalam penggunaan teknologi modern dan penggunaan iptek. 


\section{Metode Penelitian}

Penelitian ini dilakukan melalui studi pustaka sebagai langkah untuk mendapatkan informasi-informasi yang terkait dengan model pembelajaran berbasis Aktif leaning. Studi pustaka ini merupakan metode utama dalam penelitian ini sebagai panduan untuk mengumpulkan data yang diperlukan. Waktu untuk menyelesaikan penelitian ini sekitar dua minggu, metode analisis yang cocok digunakan oleh peneliti yaitu metode analisis deskriptif kualitatif. Diharapkan dengan menggunakan metode tersebut mendapatkan data yang terarah, cocok, dan mendalam, sehingga bisa memberikan solusi atas persoalan-persoalan yang ada pada pembelajaran Pendidikan Agama Islam. Tempat penelitian ini dilakukan di IAIN metro, teknik pengumpulan data dengan observasi dan dokumentasi. Sumber informasi penelitian ini dengan membaca buku-buku di perpustakaan, langkah ini dilakukan supaya peneliti mendapatkan informasi yang kuat.

\section{Hasil penelitian}

Pelaksanaan penggunaan model pembelajaran berbasis Aktif Learning dalam meningkatkan hasil belajar siswa mata pelajaran akhlak.

Model Pembelajaran aktif sendiri merupakan proses belajar yang membuat siswa berperan dalam menyampaikan pendapat dan memberikan ide atau pemikiran yang ada pada dirinya dan disampaikan di dalam kelas (Handayani, 2011). Model pembelajaran stad ini adalah model pembelajaran yang mengutamakan kerjasama diantara siswa untuk mencapai tujuan pembelajaran. Tipe Stad ini memiliki ciri utama yaitu memotivasi siswa dalam satu kelompok untuk saling memberi semangat dan adanya penghargaan yang dapat memotivasi siswa untuk lebih baik dalam menghadapi kuis individu yaitu memperoleh skor terbaik. Setiap peserta didik diberikan sebuah skor dasar yang dihitung dari kinerja rata-rata peserta didik pada kuis yang sama sebelumnya. lalu peserta didik mendapatkan nilai atau poin untuk kelompoknya disamakan pada banyaknya nilai kuis mereka melebihi nilai awal mereka. inti dari Student Teams Achievement Devisions (STAD) adalah guru menyampaikan suatu materi, sementara para siswa tergabung dalam kelompoknya yang terdiri atas 4 atau 5 orang untuk menyelesaikan soal-soal yang diberikan oleh guru dan Selanjutnya siswa diberi kuis atau teks secara individual. Skor hasil kuis tersebut di samping untuk menentukan skor individu juga digunakan untuk menentukan skor kelompoknya.

Penghargaan tim, ketika peserta didik ingin mendapatkan penghargaan tim, maka mereka harus mendapatkan skor yang rata-rata mereka melebihi ciri tertentu. 
Yaitu skor kelompok dihitung berdasarkan presentase nilai tes mereka melebihi nilai tes sebelumnya.

Penerapan yang dilakukan oleh pendidik sangat sederhana Dalam pembelajaran tipe Stad (Student Achievement Divisions) karena memang model ini merupakan model pembelajaran kooperatif yang paling sederhana yang dapat digunakan oleh pengajar untuk memberikan materi pendidikan agama Islam (Akhlak) kepada murid di kelas, model ini sangat cocok untuk seorang guru yang baru memulai menggunakan pembelajaran kooperatif. Di dalam model ini ada empat komponen yaitu presentasi kelas, kerja kelompok, kuis, dan juga penilaian kelompok. Dalam penerapannya hal yang utama dilakukan adalah guru menyampaikan materi pembelajaran atau permasalahan kepada siswa sesuai kompetensi dasar yang akan dicapai, lalu guru memberikan kuis/tes kepada siswa secara individual sehingga akan diperoleh skor awal dan selanjutnya guru membentuk beberapa kelompok. Setiap kelompok terdiri dari 4-5 siswa dengan kemampuan yang berbeda-beda (tinggi, sedang, dan rendah), lalu bahan materi yang telah dipersiapkan didiskusikan dalam kelompok untuk mencapai kompetensi dasar, guru memfasilitasi siswa dalam membuat rangkuman, mengarahkan, dan memberikan penegasan pada materi pembelajaran yang telah dipelajari dan terakhir guru memberikan penghargaan pada kelompok berdasarkan perolehan nilai peningkatan hasil belajar individual dari skor dasar ke skor kuis berikutnya sehinga semua murid merasa bahwa pekerjaannya tersebut dihargai oleh guru (Hendrik, 2006). Model ini mengajak semua siswa bekerjasama dan saling membantu antar sesama kelompok untuk mencapai keberhasilan belajar, dan menggunakan metode kuis untuk mengukur pemahaman konsep siswa (Nuroso, 2012).

Model ini memiliki keunggulan ketika diterapkan dalam pembelajaran Akhlak, model ini akan dapat memberikan kontribusi kepada siswa ketika mereka sedang bekerjasama dan dapat menigkatkan pemahaman serta saling tolong menolong dalam kelompok yang memberikan kesan bahwa mereka dapat menerapkan Akhlak yang baik sesama teman, karena dalam bekerjasama dan tolong menolong merupakan akhlak yang baik.

kekurangan yang dimiliki model pembelajaran ini adalah kadangkala ada siswa yang masih saja belum memahami materi yang disampaikan dan guru sulit dalam pengelompokan siswa yang mempunyai kemampuan heterogen dari segi pengetahuan, dan guru akan dapat mengatasinya jika guru yang bertindak sebagai pemegang kendali teliti dalam menentukan pembagian kelompok waktu yang dihabiskan untuk diskusi oleh siswa cukup banyak sehingga melewati waktu yang 
p-ISSN: 1412-1697; e-ISSN: 2477-3816

http://jurnal.radenfatah.ac.id/index.php/intizar

sudah ditetapkan, dan masih adanya siswa yang berkemampuan tinggi yang masih sulit untuk menjelaskan kepada teman-temannya. Sedangkan kelebihan model pembelajaran ini meningkatkan kerjasama dalam melaksanakan tugas yang diberikan, meningkatnya pemahaman siswa terhadap materi, keterlibatan siswa yang seimbang dan lebih tinggi dalam belajar bersama, melatih kesiapan siswa, saling membantu dan memberikan pengetahuan (Muhamad, 2015, hal. 54). Dari apa yang telah peneliti baca banyak sekali guru yang dapat menjadikan anak didiknya dikelas belajar dengan aktif sehingga pelajaran Akhlak yang dahulunya sangat sulit dan membuat anak malas mempelajarinya ketika telah menerapkan model pembelajaran berbasis Aktif Learning ini menjadi sangat disenangi oleh murid dan mereka sangat gembira dan bersemangat dalam belajar.

\section{Pembahasan}

Aktualisasi akhlak dalam pendidikan dapat dilakukan menggunakan beberapa strategi, yaitu: pertama, dengan mengintegrasikan konten kurikulum pendidikan akhlak yang telah dirumuskan ke dalam seluruh mata pelajaran yang sesuai, terutama mata pelajaran agama dan kewarganegaraan. Kedua, mengintegrasikan pendidikan akhlak ke dalam kegiatan yang diprogramkan atau direncanakan. Ketiga, dengan membangun komunikasi dan kerjasama antara lembaga pendidikan dengan orang tua peserta didik, dan keempat, mengoptimalkan keteladanan guru (pendidik), karena "pendidik merupakan teladan yang harus ditiru, yang dapat mentransformasikan ilmu pengetahuan, nilai-nilai sosial, moral dan keagamaan yang berangkat dari pemahaman konsep pendidikan yang benar. Seorang pendidik sebaiknya mentransfer pemahaman mengenai pendidikan "bahwa pendidikan adalah suatu usaha atau aktivitas untuk membentuk manusia-manusia yang cerdas dalam berbagai sisi, baik pengetahuan, sosial, emosional maupun spiritual, trampil serta berkpribadian dan dapat bertingkah laku dengan dihiasi akhlak mulia, disamping itu juga untuk mencocokan pembentukan akhlak dalam pendidikan perlu adanya pendekatan profetik (pendekatan kenabian) dalam mengaktualkan akhlak yang komprehensif, yaitu, pertama, mendekatkan peserta didik pada kitab suci, mendekatkan peserta didik pada tempat ibadah, mendekatkan peserta didik dengan para pendidik (Subahri, 2015).

Metode pendidikan akhlak yang dikatakan Al-Ghazali bahwa memiliki dua cara dalam mendidik akhlak, yaitu; pertama, mujahadah dan membiasakan latihan dengan amal shaleh. Kedua, perbuatan itu dikerjakan dengan ulang-ulang. Kedua, akhlak tersebut diusahakan dengan mujahadah dan riyadhah, yaitu dengan 
membawa diri kepada perbuatan-perbuatan yang dikehendaki oleh akhlak tersebut. Dapat kita pahami akhlak berubah dengan pendidikan latihan (Rohayati, 2011).

Menanamkan rasa takut kepada Allah diarahkan untuk menjalankan semua perintah Allah dan menjauhi semua larangannya, pendidik memberikan pembiasaan terhadap peserta didiknya sehingga akan menjadi perwatakan, atau terbiasa dengan sendirinya (Zainudin, 2013).

Meningkatkan hasil belajar mata pelajaran Akhlak, guru harus melakukan sesuatu yang berbeda sehingga peserta didik lebih cepat faham. Apabila guru akan membentuk akhlak muridnya ketika menggunakan ceramah maka harus dikolaborasikan dengan metode diskusi dan Tanya jawab dan metode uswah atau pencontohan yang langsung dilakukan dalam kehidupan sehari-hari, uswah ini akan berhasil ketika seorang guru memiliki nilai-nilai iman yang kuat dan benar serta selalu dalam ketaqwaan lahir bathin, berakhlak mulia, sehingga secara sengaja maupun secara spontan ucapan, sikap dan perilakunya sesuai dengan nilai-nilai Islam. Jadi disadari atau tidak akan berpengaruh dan ditiru oleh setiap murid yang diajarkan (Nasution, 2015). Fungsi dalam mempelajari Akhlak adalah dapat mewujudkan kesejahteraan di tempat tinggal kita dikarenakan akhlak adalah symbol kehidupan yang nyaris tertinggal, namun kita perlu tahu bahwasanya akhlak merupakan suatu media yang baik dalam melakukan suatu hubungan kemasyarakatan, dengan adanya akhlak segala hal yang berat menjadi ringan, dikarenakan segala kesulitan akan banyak yang membantu ketika setiap orang memiliki akhlak yang baik, sehingganya dapat memberikan kebaikan dan mewujudkan kesejahteraan masyarakat.

Dahulu permasalahan yang datang memberikan keadaan yang berbeda dari hari ini, banyak yang tidak mengerti bahwa akhlak ini dapat mengungkapkan masalah dengan objektif, ketika itu dalam masyarakat luas objektifitas lebih dipercaya daripada unsur subjektif ini menjadi model bagi akhlakul karimah diterima sebagai sebuah konsep yang mampu memberikan jaminan manusia untuk selamat dunia dan akhirat. Perkataan tersebut pasti harus kita percayai bahwasanya akhlak mampu memberikan jaminan manusia untuk selamat dunia dan akhirat, dan meningkatkan motivasi untuk menggali ilmu manfaat dari akhlak sendiri adalah membawakan keberuntungan bagi manusia, keberuntungan tersebut adalah memperkuat dan menyempurnakan agama, mempermudah perhitungan amal di akhirat bahwasanya Nabi bersabda, artinya: ada tiga perkara yang membawa kemudahan hisab (perhitungan amal di akhirat) dan akan dimasukkan ke surga yaitu engkau memberi sesuatu kepada orang yang tak pernah memberi apapun kepadamu 
p-ISSN: 1412-1697; e-ISSN: 2477-3816

http://jurnal.radenfatah.ac.id/index.php/intizar

(kikir), engkau memaafkan orang yang pernah menganiayamu dan engkau menyambung tali silaturahmi kepada orang yang tak pernah kenal padamu. (Hr. Alhakim), menghilangkan kesulitan nabi bersabda, barangsiapa melepaskan kesulitan orang mu'min dari kehidupannya di dunia ini, maka Allah akan melepaskan kesulitan orang tersebut pada hari kiamat. (HR. Muslim), dan selamat hidup di dunia dan akhirat

Nabi bersabda, artinya: ada tiga perkara yang dapat menyelamatkan manusia, yaitu takut kepada Allah di tempat yang tersembunyi maupun di tempat yang terang, berlaku adil pada waktu rela maupun pada waktu marah dan hidup sederhana pada waktu miskin, maupun waktu kaya. (Hr Abu Syaikh)

Penjelasan di atas hanyalah sebagian kecil saja dari keberuntungankeberuntungan yang didapat ketika berakhlak mulia, masih banyak lagi keberuntungan-keberuntungan yang belum dapat dituliskan di sini, semoga dengan mengetahui dari manfaat akhlak, kita dapat berlomba-lomba dalam memperbaiki diri kepada kebaikan (Nata, 2015).

\section{Kesimpulan}

Dalam meningkatkan hasil belajar mata pelajaran Akhlak dengan menggunakan model pembelajaran berbasis Aktif Learning ini adalah suatu gagasan yang bagus dan mendukung belajar anak, karena di dalamnya anak bukan hanya mendengar dan menulis saja, melainkan dapat menyampaikan pendapatpendapatnya secara individu maupun kelompok. Sehingga semua murid dapat belajar dengan aktif dan mereka cepat faham dengan pelajaran akhlak secara keseluruhan. Pendidikan berhasil ketika murid yang belajar di lembaga tersebut berhasil memahami dan mendapatkan hasil belajar yang bagus. Hasil belajar menjadi tolak ukur berhasil atau tidaknya seorang murid, murid juga dapat merasakan bahwa pendidikan Akhlak memberikan manfaat bukan hanya untuk mereka sendiri melainkan orang lain disekitarnya. Maka wajib bagi peserta didik memahami pelajaran Akhlak supaya mereka dapat bersosialisasi di masyarakat dengan baik, dan mengerti cara menghormati sesama manusia. 


\section{Daftar Pustaka}

Arifin, Z. (2012). Evaluasi Pembelajaran. Remaja Rosdakarya: Bandung.

Arsiyati, Y. (2012). Peningkatan Hasil Belajar IPA Siswa Kelas IX Melalui Pembelajaran Kooperatif Tipe Jig Saw Di MTs Al Ikhlas Tanuraksan Kebumen Tahun Pelajaran 2011/2012. Radiasi, 1(1).

Handayani, B. D. (2011). Efektivitas Pembelajaran Aktif Melalui Penerapan Model Pembelajaran Kolaboratif (Collaborative Learning) Untuk Meningkatkan Prestasi Belajar Akuntansi Sektor Publik Pokok Bahasan Akuntansi Satuan Kerja Pengelola Keuangan Daerah (Skpkd). Dinamika Pendidikan, 6(1).

Hendrik, A. L. (2006). Pengaruh Pembelajaran Kooperatif Model Stad Dan Gaya Kognitif Terhadap Hasil Belajar Fisika Siswa Sma. Jurnal Ilmu Pendidikan, 13(2).

Irwandra. (2014). Metafisika Akhlak: Dasar-Dasar Akhlak Dalam Islam. ANIDA, $39(1)$.

Mahdi. (2016). Urgensi Akhlak Tasawuf Dalam Kehidupan Masyarakat Modern. Edueksos: Jurnal Pendidikan Sosial \& Ekonomi, 1(1).

Maisaroh, \& Rostrieningsih. (2010). Peningkatan Hasil Belajar Siswa Dengan Menggunakan Metode Pembelajaran Active Learning Tipe Quiz Team Pada Mata Pelajaran Keterampilan Dasar Komunikasi Di Smk Negeri 1 Bogor. Jurnal Ekonomi \& Pendidikan, 8(2).

Majid, A. (2013). Strategi Pembelajaran. Bandung: Remaja Rosdakarya.

Muhamad, F. (2015). Model Model Pembelajaran Inovatif. Yogyakarta: Ar-Ruzz Media.

Nasution, N. H. (2015). Metode Dakwah Dalam Membentuk Akhlak Mahmudah Remaja. Wardah, 12(2).

Nata, A. (2015). Akhlak Tasawuf dan Karakter Mulia. Jakarta: Raja Grafindo Persada.

Nilyati. (2015). Sistem Pembinaan Akhlak Dalam Tasawuf Akhlaki. Tajdid, 13(2). Nuroso, D. N. (2012). Penerapan Model Stad Termodifikasi Pada Mata Kuliah Fisika Lingkungan Ditinjau Dari Kemampuan Berpikir Kritis Mahasiswa. Jurnal Penelitian Pembelajaran Fisika, 3(1).

Nurwati, T. (2010). Peningkatan Aktivitas Dan Hasil Belajar Mata Diklat Produktif Pemasaran Dengan Menggunakan Metode Inkuiri Pada Siswa Kelas Xi Pemasaran Smk Negeri 02 Purworejo Semester Genap Tahun 2010/2011. Jurnal Ekonomi \& Pendidikan, 8(2). 
Rohayati, E. (2011). Pemikiran Al-Ghazali Tentang Pendidikan Akhlak. Ta'dib, $16(1)$.

Subahri. (2015). Aktualisasi Akhlak Dalam Pendidikan. Islamuna: Jurnal Studi Islam, 2(2).

Wahyudi, D., \& Alafiah, T. (2016). Studi Penerapan Strategi Pembelajaran Berbasis Multiple Intelligences dalam Mata Pelajaran Pendidikan Agama Islam. MUDARRISA: Jurnal Kajian Pendidikan Islam, 8(2).

Wahyudi, D., \& Azizah, H. (2016). STRATEGI PEMBELAJARAN MENYENANGKAN DENGAN KONSEP LEARNING REVOLUTION. ATTARBIYAH, 26.

Zainudin. (2013). Pendidikan Akhlak Sebagai Tuntutan Masa Depan Anak. Ta'allum: Jurnal Pendidikan Islam, 1(2). 
Dedi Wahyudi \& Mahmudatun Hasanah

Penggunaan Model Pembelajaran Berbasis Aktif Learning Tipe STAD untuk Meningkatkan Hasil Belajar Peserta Didik pada Mata Pelajaran Aqidah Akhlak

Intizar, Volume 23, Nomor 2, 2017 